\title{
Irish Poetry and Its Contribution to European Literature
}

\author{
Nora Hadi Q. Alsaeed ${ }^{1}$ \\ ${ }^{1}$ English Department, College of Administrative and Humanities Sciences, Al Jouf University, Sakaka, KSA \\ Correspondence: Nora Hadi Q. Alsaeed, Assistant Professor, English Department, College of Administrative and \\ Humanities Sciences, Al Jouf University, Sakaka, KSA. E-mail: nora.h.alsaeid@ju.edu.sa
}

$\begin{aligned} & \text { Received: September 14, } 2015 \\ & \text { Accepted: September 29, } 2015 \quad \text { Online Published: November 29, } 2015 \\ & \text { doi:10.5539/ells.v5n4p27 }\end{aligned}$ URL: http://dx.doi.org/10.5539/ells.v5n4p27

\begin{abstract}
Irish poetry is considered one of the oldest and most enriched sources of poetry in Europe. As a small nation with a less prominent contribution to world literature, the Irish have benchmarked some of their brightest examples in the form of Gaelic writings, and present an outstanding account of oral traditions and oral poetry that have passed down the generations to the contemporary 21 st century. Their literature represents various facets of Irish culture, history, and socio-cultural aspects reflected through magical verses of poems, the nature of which has transcended generations and established itself in the history of Europe.
\end{abstract}

Keywords: Irish poetry, European literature, Yeats, Irish culture

\section{Introduction}

Irish poetry is considered one of the oldest and most enriched sources of poetry in Europe. As a small nation with a less prominent contribution to world literature, the Irish have benchmarked some of their brightest examples in the form of Gaelic writings, and present an outstanding account of oral traditions and oral poetry that have passed down the generations to the contemporary 21st century (Aberdeen \& Temair, 2005). Their literature represents various facets of Irish culture, history, and socio-cultural aspects reflected through magical verses of poems, the nature of which has transcended generations and established itself in the history of Europe (Auge, 2013).

The developmental phases and transformations that Irish poetry continues to have in the modern globalized world attract the attention of scholars and academics alike. There has been a renaissance of studies and research of the annals of history, browsing the pages of archives to examine and devolve the various phases of this magnificent era of literature. This includes the geniuses it has given birth to, many of which have been buried under the snow of time and the marginalization of the Irish poetic literature, Irish themes, and Irish culture, in the broadest sense of the term (Bradley, 2008).

Irish poetry vividly explains the role played by some of the most famous writers, namely Jonathan Swift, Lawrence Sterne, Oliver Goldsmith, and Richard Sheridan, whose accounts, despite having English as their background, are considered bedrocks of contemporary Irish literary culture.

\section{Development Phases of Irish Literary Culture and Heritage}

The early phase of Irish poetry was marked primarily with poems and verses scripted and articulated by eminent poets and writers praising the achievements and worthiness of the king, and often used as propaganda tools expounding the efficacy of the kingdom and its prevailing welfare. In the early days of Irish poetry, the work described and reflected aspects related to the world of nature, wisdom, and the entertainment purposes of poetry, and were necessarily representative of the pre-Christian era Ireland (Buachalla, 2002).

Irish poetry has evolved with time and has assumed attributes and features that can only be explained if one goes through the annals of the developmental and evolutionary phases it has experienced before assuming the character it currently reflects.

The medieval phase of Irish poetry was marked with the era of the bards, professionals appointed by the king with an official role to perform in praising the lord for worthiness and rubbishing those who dared go against the king or who were found guilty of disobedience. As such, modern scholars and readers hardly classify their works as being quintessential poetry, as they contained merely the facts and figures representing the achievements and greatness of their kings (Campbell, 2003). 
However, in stark contrast with the erstwhile eras or phases, the Gaelic era represented the decline and erosion of the political power of the kings and changes in the world order, with the bards losing their professional status and stature. Hence, such verses are marked with accounts of the decline in poets' status, and their plight. This era was also marked with the transition of the bards into folk poets, until the revival of the Gaelic system.

The subsequent era saw the genius of Jonathan Swift, whose accounts Gulliver's Travels and A Tale of a Tub presented masterful skills and his exalted style of writing. These works remain preserved as genius examples of Irish poetry (Chaudhry, 2001).

Hand-in-hand with the Romantic movement in Europe, cultural nationalism in Ireland gained momentum via people commonly known as the "Young Irelanders." These men were renowned for their contribution to what came to be known as the Irish renaissance, upholding the distinctiveness and grandeur of Irish idealism and imaginary masterfulness. The account of the ballads, provided by Duffy, bears testimony to this deep sense of being Irish and their endeavor to uphold and carry forward the Irish identity and national heritage, coupled with a sense of outrage and nationalism against the erosion of Irish heritage and literary culture at the hands of the advocates of the English language and literary heritage. The movement to bolster support for the Irish identity was also endorsed by Ferguson, who did more than anyone in translating prominent writings into Irish and joining the awareness and promulgation campaign for nationalism of the Irish identity and quintessential fervor (Kenneally, 2005).

The movement and efforts propagated and advocated by Yeats have been deciphered and discussed in the context of his dedication and determination to establish a literature canon for the Irish people and Irish culture, so as to enable Irish poetry and literary culture to be "beautifully remembered in memory" (Schleifer, 2000). This era was marked with cultural nationalist revivalism, prominent movements and organizations that helped Irish cultural nationalism flourish and reach new heights with the institutional support of the National Dramatic Society and the Gaelic Athletic Association, not to name those already mentioned in the preceding parts of this paper (MacDonagh, 2001)

The 19th century witnessed the Irish language being dominated by English, but there were saviors in the form of Callanan and Ferguson, who strived to revive the poetic heritage and saga of the Irish themes and materials of poetry, which is also brightly reflected in their poems. Modern Irish poetry is marked with the works of Yeats and Heaney, of the Northern school, and Irish literature and its revival have since gone through multiple phases and annals before transcending into its present form (Dillon, 2008). The accounts of the works of these two writers are considered as bearing the essence of Irish poetry in that era.

\section{Irish Literary Revival and Yeats}

William Butler Yeats is ranked among the greatest poets of the 20th century, and apart from his caliber in the field of poetry qua, his role in the revival of Irish poetry and literature means he is of great interest to academics and students. Indeed, the revival of Irish literature and the poetic saga owes much to the efforts and role of Yeats.

Yeats, the son of the famous painter John Butler Yeats, was born in Dublin and spent a considerable part of his early days in the rural Irish countryside. The intimacy and affinity towards the Irish literary culture and poetic saga can be attributed to his upbringing and his subsequent encounters with the personalities of Fenian John O' Leary and Standish James O'Grady, who influenced him in the Irish literary heritage and culture and provided him with the guiding force and inspiration that led to the foundation of the National Literary Society. Through its establishment, a new era of revival for Irish literary culture and heritage was marked by playing an instrumental role in collecting and publishing the folklore and literary accounts of classical Irish verse (Dorgan, 1996).

Amongst the great works, the collection The Wanderings of Oisin (1889) is regarded as Yeats' most outstanding. The revival of the Irish literary culture and heritage soon gained pace and momentum, with Dublin and London serving as the nerve centers for this revival; Yeats himself travelled between the two cities, actively organizing, articulating, and bringing together pieces of the rich Irish literary culture that had been scattered by the dominant English language and literary culture. The year 1892 would be etched in the hearts of Irish literature enthusiasts and scholars, as it saw the foundation of the Irish Literary Society, the result of the combined and selfless efforts of Yeats, Rolleston, and Duffy (Foster, 2007). Subsequently, after a renaissance of quintessential Irish accounts like The Celtic Twilight and Into the Twilight, the Gaelic League was founded, providing a platform that was pure Irish in essence and intent and marked the dawn of a new phase of Irish literary revivalism.

The recognizable features of the classical style of Irish literature or poetry were simplicity and sophistication based on themes that helped provide an imaginative experience of happenings, reflected by virtue of the verses in the mind of the reader; it cast a magical spell through the exalted style and minute description of the natural 
world or the intrinsic things that form the core of the poem. It is absolutely no wonder, as the advocates of classical Irish literature put it, that the English writers of the subsequent post 19th century times sought to imitate the themes and style of expression of the Irish accounts, and aimed to reflect the exclusiveness and uniqueness of Irish poetry in their borrowed style. The efforts of Yeats and the others mentioned above were directed towards this, with the unflinching determination to represent the uniqueness and distinctiveness related to it being purely Irish, of Irish poetry that was different and much superior, in a sense, from and to the English literary literature that had overshadowed the former until recently (Goodby, 2000).

The analysis of modern-day Irish poetry or literature, at large, presents an account of the range of social, cultural, and political forces that have influenced, shaped, and molded the Irish literary stature in modern times. The poems produced by writers like Yeats and Joyce provide evidence of the influence of events such as the Irish war of independence, the role and influence of the Irish Catholic Church, and the social and political dynamics that have attributed characteristic features to the contemporary Irish literary culture (Goodby, 2000).

\section{The Uniqueness of Irish Verse}

As mentioned above, Irish literature is one of the oldest and most enriched literary heritages in Europe, and is characterized by the beauty of the natural world and the prevalence of the Gaelic system. Indeed, the prevalence of the Gaelic system and the manner in which Irish literature reflected aspects of the beauty of the natural world provided it with a special status in European literature. The accounts provided by Kuno Meyer are of special significance, as he upholds the uniqueness and distinctiveness of Irish poetry and literature, and famously states that attention to the minutest detail of the environment or nature formed the base of the grandest essence of the Irish literary culture, one that holds a central position on the world literary platform (Hoagland, 2007).

As Brendan Kennelly appropriately put across in the Penguin Book of Irish Verse (2010), when discussing the single most astounding quality of Irish poetry, "a, hard, simple, virile, rhetoric clarity is its most memorable and valued characteristic" (Ingraham, 2002). The quintessential essence of the Irish poetic and literary heritage, if Kennelly is to be quoted, rested on the "delight to simple, direct and lively expression with absolute emphasis on accurate observation and precise diction," and this formed the base that distinguished it from other fields of literature anywhere else in the world (Johnston, 2005).

Another astounding feature of Irish literary culture and poetry is essentially related to aspects of traditional transitional continuity and rifts with the traditions in Irish literature, as marked with rifts among the writers and poets themselves (Wall, 1995).

\section{Conclusion}

The history of Irish poetry is long and complex in nature. The vernacular literature and poetry in the Irish language is considered the oldest of all literature in the world, and even today there is maintained a continuous tradition of the Irish culture, which began in the 6th century, by way of its dominant role in Irish literature and poetry. However, from the 14th century onwards, some Irish poets started to write poems in Irish language. The dawn of the 20th century marked the advent of the writing style propagated by Yeats, reflecting the influence of the Celtic writing style and syntax and the modern style and syntax advocated by James Joyce and Samuel Beckett. The study of Irish literature and poetry forms an integral part of the syllabus of the study of world literature, and is loaded with interesting events and aspects that have shaped and influenced Irish literature and poetry to give it the form it currently exhibits (Ryan, 2000). The investigation of the annals of history and the study of the literary evidence of some of the most noted Irish poets provides an insight into the socio-cultural and political situation when such accounts were versed. This reflects the status, stature, and dynamics of Irish literature and poetry at such times through the form of the verses that dominated the Celtic and Gaelic writings, which provides a major construct in the discourse of the study of world literature (Maguire, 2002).

The distinctive syntax, manner of expression, and the emphasis on themes related to the natural world representing a strong sense of satire form the basis of the classical Irish literature and poetry that have astounded and intrigued scholars, historians, and academics for a long time (Robinson, 2013).

The movements and events of the civil war, the independence war, and the Irish literary renaissance have been important landmarks on the path of the transcending of Irish poetry and literature from the 15th century onwards. The accounts of Yeats and Ferguson, and accounts of exemplary works in the pre-modern and modern times, provide literary evidence of the diverse and varied nature of the characteristic features of Irish literature and poetry. With the passage of time, it evolved and was molded by forces of time and circumstances to assume the characteristic features that it displays in the modern globalized world (McSweeney, 2001).

Although largely a marginalized faction of research studies and academic scrutiny, the literary accounts of Irish 
literature and poetry have never failed to strike the innermost chords of readers by presenting a wonderful metamorphosis of the events and circumstances in response to which these verses were scripted and articulated. It has been correctly stated that the history of Irish literature and poetry essentially represented the political, social-cultural, and economic transition of Irish society and culture at large. Such events have found the best representation through superior poetic verses and the accounts of eminent writers who marked the dawn and the subsequent revival of Irish heritage and literary esteem in the world of literature. They helped carve out a distinct and unique niche for Irish writings and poetic accounts that had until then been suppressed or overshadowed by dominant languages like English (Potts, 2014).

Irish literature and poetry reflects the rich literary heritage of Europe in general, and Irish works in particular, and the study of the accounts of eminent writers through the ages and eras provides evidence of the richness and deepness of Irish literary and poetic traditions.

\section{References}

Aberdeen and Temair, Ishbel Gordon, Marchioness of, 1857-1939. (1895). The Irish literary revival: a lecture delivered at the request of the Catholic Young Ladies' Literary Association. Retrieved from http://eco.canadiana.ca/view/oocihm.08069

Auge, A. (2013). A chastened communion. Syracuse, NY: Syracuse University Press.

Bradley, A. (2008). Contemporary Irish poetry. Berkeley, CA: University of California Press.

Buachalla, B. (2002). Irish Jacobite poetry. The Irish Review, 12, 40-49.

Campbell, M. (2003). The Cambridge companion to contemporary Irish poetry. Cambridge: Cambridge University Press. http://dx.doi.org/10.1017/CCOL0521813018

Chaudhry, Y. (2001). Yeats, the Irish literary revival, and the politics of print. Cork, Ireland: Cork University Press.

Dillon, M. (2008). Early Irish literature. Chicago, IL: University of Chicago Press.

Dorgan, T. (2006). Irish poetry since Kavanagh. Blackrock, Co. Dublin, Ireland: Four Courts Press.

Foster, J. (2007). Fictions of the Irish literary revival. Syracuse, NY: Syracuse University Press.

Goodby, J. (2000). Irish poetry since 1950. Manchester, UK: Manchester University Press.

Hoagland, K. (2007). 1000 years of Irish poetry. New York, NY: Devin-Adair Co.

Ingraham, V. (2002). Literature from the Irish literary revival. Washington DC: University Press of America.

Johnston, D. (2005). Irish poetry after Joyce. Notre Dame, IN: University of Notre Dame Press.

Kenneally, M. (2005). Poetry in contemporary Irish literature. Gerrards Cross, Buckinghamshire: Colin Smythe.

MacDonagh, T. (2001). Ancient Irish poetry. The Irish Review (Dublin), 1(2), 84. http://dx.doi.org/10.2307/30062664

McSweeney, K. (2001). J. Stanyan Bigg's “An Irish Picture.” Victorian Poetry, 39(3), 407-411. http://dx.doi.org/10.1353/vp.2001.0031

Maguire, M. (2002). New Irish poetry. The Irish Review (Dublin), 2(16), 186. http://dx.doi.org/10.2307/30062825

Potts, D. (2014). Pastoral elegy in contemporary British and Irish Poetry: Knowing one's place in contemporary Irish and Polish poetry. English, 63(243), 349-351. http://dx.doi.org/10.1093/english/efu021

Robinson, P. (2013). The Oxford handbook of contemporary British and Irish poetry. Oxford: Oxford University Press. http://dx.doi.org/10.1093/oxfordhb/9780199596805.001.0001

Ryan, W. (2000). The Irish literary revival. New York: Lemma Publishing Corp.

Schleifer, R. (2000). The genres of the Irish literary revival. Norman, OK: Pilgrim Books.

Wall, R. (2005). A dictionary and glossary for the Irish literary revival. Gerrards Cross, Buckinghamshire: Colin Smythe.

\section{Copyrights}

Copyright for this article is retained by the author(s), with first publication rights granted to the journal.

This is an open-access article distributed under the terms and conditions of the Creative Commons Attribution license (http://creativecommons.org/licenses/by/3.0/). 